\title{
Extraordinary Renditions and State Secrets: A Human Rights Approach
}

\author{
Juliana Gil Borenstein*
}

DOI: $10.21827 / 5 \mathrm{~d} 5141 \mathrm{~b} 011 \mathrm{de} 5$

\section{Keywords \\ STATE SECRETS PRIVILEGE; NATIONAL SECURITY; HUMAN RIGHTS; COUNTER-TERRORISM; EXTRAORDINARY RENDITION}

\begin{abstract}
One of the world's main concerns over the past decades has been the phenomenon of terrorism. It is evident that terrorism must be eradicated, especially considering the huge threat it poses to the basic values of democratic societies. However, it must be kept in mind that arbitrary governments also represent a huge threat to these same values and, therefore, safeguards must exist to guarantee that state authorities act within the framework of law. Unfortunately, some governments misuse the 'state secrets privilege' argument, created to protect their right to confidentiality in national security affairs, to prevent their gross violations of human rights from being assessed by the judiciary, violating victims' rights and promoting impunity. This is particularly true in cases involving so-called 'extraordinary renditions' used to fight terrorism. This article defends the premise that as much as the existence of secrecy is essential for the protection of every nation, no secrecy can serve as an excuse for governments to violate human rights and disregard the rule of law. In order to ensure that state secrets privilege is not used as a way to promote impunity for serious human rights violations, it is very important that mechanisms are implemented in order to have the claim of secrecy in national security related issues closely scrutinised by an impartial judicial organ. It is in the interest of democracy and justice that a fair balance is struck between the interests of national security and the protection of human rights.
\end{abstract}

\section{Introduction}

The terrorist attacks of September 11, 2001 made terrorism one of the greatest fears of governments and people all over the globe. Although terrorism is far from being the most prevalent cause of death in any given society, it has had a huge impact in the collective mind nonetheless. This can be explained not only because of mass media, but also due to terrorism's unpredictability, large scale organisation and to the extent of terrorism's impact on global economics and politics. Moreover, terrorism has an immeasurable impact on human rights, as it aims at the destruction of the values that are the very core of the Charter of the United Nations and human rights law in general, undermining the foundations of democracy and the rule of law. As such, fighting terrorism has become a priority for many governments and all sorts of measures and intergovernmental cooperation were/are being developed in order to do so. It is self-evident that states have the duty to protect their nationals against all threats, terrorism included, taking positive measures to protect them from terrorism threat and to hold 
terrorists accountable for their actions. Efforts to eradicate terrorism are praised and they must be taken.

However, it is now widely known that in their restless effort to fight terrorism governments have often used disproportionate force and acted arbitrarily, continuously breaching their obligations under international human rights law. ${ }^{1}$ One of their most controversial measures adopted so far is the extraordinary rendition by which states transfer, without any legal process, a person to the custody of another state in order for them to be detained and interrogated. During this procedure, it is alleged that individuals detained are more often than not subject to all kinds of cruel and inhumane treatment, and that the rule of law is completely disregarded in the process. ${ }^{2}$ Presumption of innocence is a principle which seems to be unknown to those who carry out this kind of procedure, and charges are very often not brought before the courts against the so called 'suspects of terrorism' who are subject to the measure.

While terrorists' activities 'negate everything that human rights represent', ${ }^{3}$ extraordinary renditions and secret detentions are not less harmful to human rights. There are cases in which individuals remain under government custody for months or years, without any access to a lawyer or being able to contact their families. Under these conditions, some individuals are known to have died in detention ${ }^{4}$ and others are simply released after some time without any or little explanation, as the cases below will demonstrate.

Victims sometimes try to obtain some kind of redress for the violation of their basic rights before a court, a right which is well established under customary international law. ${ }^{5}$

As examples of such disproportionate and arbitrary acts disclosed to the public, the Special Rapporteur mentioned in his report that the site Wikileaks published numerous diplomatic reports confirming the existence of secret detentions and illegal transfers of detainees. In addition, the American soldier Bradley Manning is facing charges for refusing to continue to take part in illegal activities of the government during counter-terrorism operations and to cover them up, handling classified documents to the referred site confirming the said abuses. See Parliamentary Assembly of the Council of Europe (Committee on Legal Affairs and Human Rights) 'Abuse of State Secrecy and National Security: Obstacles to Parliamentary and Judicial Scrutiny of Human Rights Violations' (16 September 2011) Doc. 12714 3, 20. Moreover, the German Chancellor Angela Merkel told a press conference that the United States had admitted that it had made a mistake of identity in relation to the case of Mr. El-Masri, where he was subject to the extraordinary rendition programme of the CIA for being suspect of terrorism and then tortured by the United States. See Amrit Singh, 'European court of human rights finds against CIA abuse of Khaled el-Masri' (The Guardian 13 December 2012) <www.theguardian.com/commentisfree/2012/dec/13/european-court-human-rightscia-abuse-khaled-elmasri>accessed 12 May 2019.

The Committee on International Human Rights of the Association of the Bar of the City of New York and The Centre for Human Rights and Global Justice, Torture by Proxy: International and Domestic Law Applicable to "Extraordinary Renditions"' (ABCNY \& NYU School of Law 2004); Robert Verkaik, 'The Big Question: What is extraordinary rendition, and what is Britain's role in it?' (Independent 8 June 2006) $<$ www.independent.co.uk/news/uk/crime/the-big-question-what-is-extraordinary-rendition-and-what-isbritains-role-in-it-481452.html> accessed 12 May 2019; Jonathan Horowitz and Stacy Cammarano, '20 Extraordinary Facts about CIA Extraordinary Rendition and Secret Detention' (Open Society Foundations, 5 February 2013) <www.opensocietyfoundations.org/voices/20-extraordinary-facts-about-ciaextraordinary-rendition-and-secret-detention>accessed 12 May 2019. Counter-Terrorism and Human Rights in Northern Nigeria' (2015) 59(1) Journal of African Law 25, 27. Andrei Scheinkman and others, 'The Guantanamo Docket: A History of the Detainee Population' New York Times (2 May 2018) <www.nytimes.com/interactive/projects/guantanamo> accessed 12 May 2019.

Hague Convention (IV) Respecting the Laws and Customs of War on Land and Its Annex: Regulations Concerning the Laws and Customs of War on Land (adopted 18 October 1907, entered into force 26 January 1910) 205 CTS 277 art 3; Universal Declaration of Human Rights (adopted 10 December 1948) UNGA Res 217 A(III) (UDHR) art 8; Convention for the Protection of Human Rights and Fundamental Freedoms 
Instead of obtaining such redress, they have their fundamental rights violated even further by the refusal of the courts to fully analyse their cases. Such refusal is justified under the 'state secrets privilege' claim used by governments in order to have the judiciary stop ruling on the issues which, according to them, must remain secret in order to protect national security. To preserve secrecy, legal doctrines such as this were created and developed in several countries. The doctrine is an evidentiary rule and is usually not provided by law. It is rather a jurisprudential construction which considers that the executive power has the prerogative to withhold information from the court, victims and/or the public if its disclosure would be able to put national security at risk. ${ }^{67}$ If the argument is accepted by the court, the state-held evidences at issue may not be admissible in the case, preventing the court from properly addressing the alleged human rights violations brought to it by the victims of those wrongful measures.

This article will focus on the judicial practice of the state secrets privilege and how it may establish impunity for human rights violations, corruption and criminal behaviour against the backdrop of the extraordinary rendition and secret detention programme carried out by the US and assisted by several other countries. The analysis herein carried out will mainly be based on an international human rights law perspective. The main question to be answered in this work is: to what extent may the state secrets privilege violate international human rights law when used in the context of extraordinary rendition and secret detention? To answer this question, extraordinary rendition and secret detention will be explained, and, subsequently, assessed as to how these measures may violate human rights. Explaining how these procedures violate human rights is important in order to show the importance of having an impartial organ scrutinising the lawfulness of government measures. The following chapter will focus in particular on the state secrets privilege and it will explain the notion and its impact on human rights. The study will be done through an analysis of the relevant case law. While this work recognises the importance of secrecy to the very existence of the national state, it will show the importance of striking a balance between national security and individual rights, since the former is the very core of the existence of any democratic nation.

(adopted 4 November 1950, entered into force 3 September 1953) ETS No. 005 (European Convention on Human Rights, as amended) (ECHR) art 13; International Convention on the Elimination of All Forms of Racial Discrimination (adopted 21 December 1965, entered into force 4 January 1969) 660 UNTS 195 (ICERD) art 6; International Covenant on Civil and Political Rights (adopted 16 December 1966, entered into force 23 March 1976) 999 UNTS 171 (ICCPR) art 2; American Convention on Human Rights (adopted 22 November 1969, entered into force 18 July 1978) 1144 UNTS 123 art 25; Protocol Additional to the Geneva Conventions of 12 August 1949, and relating to the Protection of Victims of International Armed Conflicts (Protocol I) (adopted 8 June 1977, entered into force 7 December 1978) 1125 UNTS 3 (Additional Protocol I) art 91; African Charter on Human and Peoples' Rights (adopted 27 June 1981, entered into force 21 October 1986) 21 ILM 58 (African Charter) art 7; United Nations Convention Against Torture and Other Cruel, Inhuman or Degrading Treatment or Punishment (adopted 10 December 1984, entered into force 26 June 1987) 1465 UNTS 85 (UNCAT) art 14; Convention on the Rights of the Child (adopted 20 November 1989, entered into force 2 September 1990) 1577 UNTS 3 (CRC) art 39; Rome Statute of the International Criminal Court (adopted 17 July 1998, entered into force 1 July 2002) 2187 UNTS 90 (Rome Statute) art 68, 75; See also Dinah Shelton, International Crimes, Peace and Human Rights: The Role of the International Criminal Court (Martinus Nijhoff 2000) 238; Mahmoud Cherif Bassiouni, Post-Conflict Justice (Brill 2002) 217; Basic Principles and Guidelines on the Right to a Remedy and Reparation for Victims of Gross Violations of International Human Rights Law and Serious Violations of International Humanitarian Law, UNGA Res 60/147 (16 December 2005) UN Doc. A/RES/60/147 (2006).

6 'Background on the State Secrets Privilege' $A C L U$ <www.aclu.org/other/background-state-secretsprivilege> accessed 12 May 2019; 'FAQs: What Are State Secrets' (Center for Constitutional Rights, 17 October 2007) <www.ccrjustice.org/home/get-involved/tools-resources/fact-sheets-and-faqs/faqs-what-are-statesecrets>accessed 12 May 2019. 
The role of the courts in scrutinising the legality of the executive's actions is the main weapon people have against government's arbitrariness.

\section{Extraordinary Renditions}

Only weeks after the 9/11 terrorist events the extraordinary rendition and secret detention programme was approved by the President George W Bush. ${ }^{7}$ This programme would involve the secret killing, capturing and detention of specific persons eligible for the programme. ${ }^{8}$ It is believed that the CIA was authorised to independently carry on the programme by a presidential directive signed on 17 September $2001 .^{9}$ The programme is still surrounded by a high level of secrecy, thus little is known on the number or identities of people subject to it. The little information that came to public was obtained through the individuals who have emerged from it ${ }^{10}$ through leaking of information from insiders,${ }^{11}$ through investigations conducted by inter-governmental organisations, ${ }^{12}$ and through projects developed to uncover the facts on the extraordinary rendition programme. ${ }^{13}$ Moreover, although not in many details, there have been some official acknowledgements on the existence of the programme and on the transfers of detainees to foreign governments. The Egyptian government alone has affirmed that around sixty to seventy detainees were transferred to Egypt between September 2001 and May 2005. ${ }^{1415}$ It is most likely that most detainees are transferred to the custody of foreign countries rather than being held directly by the CIA. ${ }^{15}$

In 2006, the Military Commissions Act (MCA) ${ }^{16}$ was passed by the Congress and approved by the US President, although the secret detention or extraordinary rendition programme is not authorised by any law. ${ }^{17}$ President George W Bush sought to have terrorist suspects held in Guantánamo brought before a military commission to be tried. However, in Hamadan $v$ Rumsfeld, the Supreme Court held that such commission 'lack[ed] power to

Margaret L Satterthwaite, 'The U.S. Program of Extraordinary Rendition and Secret Detention: Past and Future' in European Centre for Constitutional and Human Rights (ed), CIA- 'Extraordinary Rendition' Flights, Torture and Accountability - A European Approach (ECCHR 2009) 27, 27.

Ibid. See also Parliamentary Assembly of the Council of Europe (Committee on Legal Affairs and Human Rights), 'Secret Detentions and Illegal Transfers of Detainees Involving Council of Europe Member States: Second Report' (11 June 2007) Doc. 11302 rev. 64.

Satterthwaite (n 7) 34.

Satterthwaite (n 7) 33. See also Mohamed v Jeppesen Dataplan Inc (ND Cal 2008) 539 F.Supp.2d 1128, 1130; Adler Monica Courtney et al n 12428/09 (4 November 2009) Milan Tribunal; El-Masri v Former Yugoslav Republic of Macedonia App no 39630/09 (ECtHR, 13 December 2012).

One of the most cited comments made by a US official on the extraordinary rendition programme: 'We don't kick the [expletive] out of them. We send them to other countries so they can kick the [expletive] out of them.' Dana Priest and Barton Gellman, 'U.S. Decries Abuse but Defends Interrogations' Washington Post (26 December 2002).

See Parliamentary Assembly of the Council of Europe (Committee on Legal Affairs and Human Rights), 'Alleged Secret Detentions in Council of Europe Member States' (22 January 2006) Doc. AS/Jur (2006) 03 rev.

Ian Cobain and James Ball, 'New light shed on US government's extraordinary rendition programme', The Guardian (22 May 2013) <www.theguardian.com/world/2013/may/22/usextraordinary-renditionprogramme>accessed 12 May 2019.

'A Conversation with Michael Hayden' (Council on Foreign Relations 7 September 2007) <www.cfr.org/event/conversation-michael-v-hayden>accessed 12 May 2019; Satterthwaite (n 7) 34.

Satterthwaite (n 7) 34, 98.

Military Commissions Act of 2006 (17 October 2006) Public Law 109-366, 120 Stat 2600.

Satterthwaite (n 7) 36-37. 
proceed because its structure and procedures violate both the UCMJ [Uniform Code of Military Justice] and the Geneva Conventions. ${ }^{18}$ In 2007, the US President issued an executive order stating that the CIA carries out 'a program of detention and interrogation.' 19 Finally in 2008, the Supreme Court ruled that the Military Commissions Act of 2006 was unconstitutional. ${ }^{20}$

The extraordinary rendition and secret detention programme consists of the apprehension and transfer of the suspects, followed by their detention in secret CIA 'black sites' overseas - such as Guantanamo Bay and Bagram - or in foreign detentions, and subsequent interrogation. The detainee is allegedly stripped, subject to a body cavity search, photographed naked, dressed up in diapers, and purportedly beaten during the process. Following that, they would be restrained with handcuffs, ankle shackles and chains, blindfolded and ears covered in order to lose their sensory perception, and finally placed aboard an aircraft. ${ }^{21}$ In the detention sites, the detainee would be subject to other various types of torture (or, as defined by President George W Bush, 'alternative set of procedures'), ${ }^{22}$ such as beatings, sexual abuse and electric shocks, while often not being formally charged with any crime or granted access to lawyers, to their governments or to anything in the outside world. ${ }^{23}$ Thousands of individuals are believed to have been detained worldwide under the suspicion of terrorism since the 9/11 attacks. ${ }^{24}$ Many of them were never brought before any court, languishing in a 'legal limbo. ${ }^{25}$ The US government had been refusing to recognise them as prisoners of war or to grant them the protections of the Geneva Conventions ${ }^{2627}$ until the judgement of the Supreme Court mentioned above rejecting its policies. After the referred judgement, US government shifted its policies to recognise the application of the protection granted by the international humanitarian law to those detainees. ${ }^{27}$

\section{I.I Extraordinary Renditions and Human Rights}

First, it is important to understand the role that human rights play in the protection of democracy and of the civilian population as a whole. In totalitarian governments, such as the

Hamdan $v$ Rumsfeld (29 June 2006) 548 US 557.

Executive Order 13440 (20 July 2007) 72 Fed Reg 14140707.

Boumediene v Bush (12 June 2008) 553 US 723, 57-64.

Satterthwaite, (n 7) 38.

Satterthwaite, (n 7) 39. See also Parliament Assembly of the Council of Europe, (n 9).

Satterthwaite, (n 7) 39.

Steven MacPherson Watt, 'Torture, "Stress and Duress" and Rendition as Counterterrorism Tools' in Rachel Meeropol et al (ed), America's Disappeared: Secret Imprisonment, Detainees, and the 'War on Terror' (Seven Stories Press 2005).

ibid.

The Geneva Conventions are the main applicable law in case of armed conflict. See Geneva Convention for the Amelioration of the Condition of the Wounded and Sick in Armed Forces in the Field (First Geneva Convention) (adopted 12 August 1949, entered into force 21 October 1950) 75 UNTS 31; Geneva Convention for the Amelioration of the Condition of Wounded, Sick and Shipwrecked Members of Armed Forces at Sea (Second Geneva Convention) (adopted 12 August 1949, entered into force 21 October 1950) 75 UNTS 85; Geneva Convention Relative to the Treatment of Prisoners of War (Third Geneva Convention) (adopted 12 August 1949, entered into force 21 October 1950) 75 UNTS 135; Geneva Convention Relative to the Protection of Civilian Persons in Time of War (Fourth Geneva Convention) (adopted 12 August 1949, entered into force 21 October 1950) 75 UNTS 287.

Charles Babington and Michael Abramowitz, 'US Shifts Policy on Geneva Conventions' Washington Post (12 July 2006)

<www.washingtonpost.com/wpdyn/content/article/2006/07/11/AR2006071100094.html??noredirect= on>accessed 13 May 2019. 
fascists regimes in Italy, Germany, Spain or Portugal, the power of the state stemmed from the fear of people of a 'common enemy' that would endanger their fundamental freedoms. ${ }^{28}$ In those regimes, citizens agreed to grant an increasing power to the executive branch, believing that this would protect the population against the alleged enemy. As a result, people's individual rights and freedoms were gradually curtailed. Those measures taken by the government against the enemies, often referred to as 'terrorists', were actually more harmful to their own civilians.

The fear of terrorism triggered by the terrorist attacks that have been occurring since 2001 has in many countries had an effect of broadening the powers given to the executive branch under the premise that a centralised power can fight terrorism more effectively. As mentioned above, such an extensive power is a matter for preoccupation, since this is the main feature of totalitarian governments as well. The principle of separation of powers and the mutual oversighting among the state branches are fundamental to the existence of a democratic society. Protecting the state should mean not only protecting it from terrorist threats, but also against measures that contravenes the democratic state's core values, such as the rule of law and democracy itself.

In democratic countries politicians must seek to legitimise their policies before their people. ${ }^{29}$ The normative consensus - that is, when 'the political discourse on counterterrorism supports the same general normative position'30 - will be analysed below in relation to extraordinary renditions and the democratic values of the countries involved in the cases analysed. There is incoherence when policies contradict the ethical norms of a state, therefore, undermining them. ${ }^{31}$

When governments violate individual rights and disregard the rule of law under the justification of protecting individuals against the violations of their rights and protecting democracy, there is normative incoherence. As it will be demonstrated below, the extraordinary rendition and secret detention programme profoundly violates international human rights law and even the domestic laws of the states carrying it out. Protecting individual rights through the violation of individual rights, mainly through the commission of serious human rights violations, is incoherent when facing the values that such measures are supposed to protect: the rule of law, democracy and fundamental rights.

Most counter-terrorist measures were adopted in the context of the aftermath of a terrorist act in response to the public outcry, and in such situation legislators and official authorities tend to react quickly by issuing laws and measures which limit significantly fundamental human rights. It is in those situations in which 'states are drawn to diminish human rights protection in the face of challenges such as terrorism, that supervision and monitoring are most needed to check domestic measures against abuses of power. ${ }^{32}$ In many instances, it is highly debatable whether the measures adopted are proportionate to the actual attack or the threat.

Anna Oehmichen, 'Terrorism and Anti-Terror Legislation: The Terrorised Legislator? A Comparison of Counter-Terrorism Legislation and Its Implications on Human Rights in the Legal Systems of the United Kingdom, Spain, Germany and France' (Doctoral thesis, Leiden University 2009) 133. Peter O'Brien, 'Counter-terrorism in Europe: the elusive search for order' (2016) 25(3) European Security 366.

ibid 368 .

ibid.

Julian Lehmann, 'Limits to Counter-Terrorism: Comparing Derogation from the International Covenant on Civil and Political Rights and the European Convention on Human Rights' (2011) 8(1) Essex Human Rights Review 103, 104. 
When it comes to extraordinary renditions and secret detentions, a number of international human rights law violations are implicated, such as the right to personal liberty and security, the prohibition to torture, the right to due legal process and to fair trial, and, at times, the right to life.

Except for situations of state of emergency, when some derogations are allowed, states must entirely fulfil their obligations under international human rights law, ${ }^{33}$ which includes inter alia: the right not to be deprived of liberty unless for reasons prescribed by law and under a proceeding governed by it; the right to be informed, in a language he or she understands, of the grounds for detention and to be promptly notified of the charges against him or her; right to have access to his or her family and medical assistance; right to be brought before a competent court; the right to be tried within a reasonable time; right to be informed of his or her right to consular assistance; right to access to a lawyer. ${ }^{34}$ However, even in situations of most serious concerns threatening the life of the nation, some rights are absolute and cannot be derogated..$^{35}$ For instance, the right to not be detained for reasons that are not prescribed by law, ${ }^{36}$ the right to be informed of the reasons for the detention, ${ }^{37}$ to the access to a lawyer, and, if applicable, to family, medical and consular assistance ${ }^{38}$ to time limits to detention pending trial, ${ }^{39}$ to judicial review of the detention, ${ }^{40}$ as well as to be treated with humanity and respect for human dignity, ${ }^{41}$ which includes the right not to be ill-treated or tortured. ${ }^{42}$

It is important to notice that both international human rights law and international humanitarian law absolutely prohibit inhumane treatment and torture. ${ }^{43}$ As such, during peace or armed conflict, detainees must be kept in a facility which respects their physical and mental attributes. ${ }^{44}$ As the prohibition of torture or other inhumane, cruel or ill-treatment is

Inter-American Commission on Human Rights, 'Report on Terrorism and Human Rights' OEA/Ser.L/V/II.116 Doc.5 Rev.1 corr (22 October 2002) para 18; ICCPR (n 5) art 4.

UNGA Res 43/173 UN Doc (9 December 1988) A/Res/43/173.

Office of the High Commissioner for Human Rights, 'Core Human Rights in the Two Covenants' (September 2013)

<nhri.ohchr.org/EN/IHRS/TreatyBodies/Page\%20Documents/Core\%20Human\%20Rights.pdf>

(accessed 15 May 2019); European Court of Human Rights, 'Guide on Article 15 of the European Convention on Human Rights: Derogation in Times of Emergency' (31 August 2018) $<$ www.echr.coe.int/Documents/Guide_Art_15_ENG.pdf>accessed 15 May 2019,10-11.

ICCPR (n 5) art 9(1).

ICCPR (n 5) art 9(2).

UNCHR 'General Comment 20: Article 7 (Prohibition of Torture, or Other Cruel, Inhuman or Degrading Treatment or Punishment)' (1992) in in 'Note by the Secretariat, Compilation of General Comments and General Recommendations adopted by Human Rights Treaty Bodies' UN Doc HRI/GEN/1/Rev.9 (Vol I) para 11.

ICCPR (n 5) art 9(3), 14(3)(c).

ICCPR (n 5) art 9(4).

ICCPR (n 5) art 10.

ICCPR (n 5) art 7.

First Geneva Convention (n 26) art 12; Second Geneva Convention (n 26) art 12; Third Geneva Convention (n 12) art 17, 87; Fourth Geneva Convention (n 26) art 32; Geneva Conventions (n 26) common art 3; Additional Protocol I (n 5) art 75(2)(a), 75(2)(e); Protocol Additional to the Geneva Conventions of 12 August 1949, and relating to the Protection of Victims of Non-International Armed Conflicts (Protocol II) (adopted 8 June 1977, entered into force 7 December 1978) 1125 UNTS 609 (Additional Protocol II) art 4(2)(a), 4(2)(h); UDHR (n 5) art 5; ICCPR (n 5) art 7; UNCAT (n 5) art 2(2); ECHR (n 5) art 3; American Convention on Human Rights (n 5) art 5(2); African Charter (n 5) art 5; Arab Charter on Human Rights (adopted 22 May 2004, entered into force 15 March 2008) reprinted in 12 Intl Hum Rts Rep 893 (2005) art 8.

Inter-American Commission on Human Rights (n 33) para 138. 
absolute and non-derogable, any information obtained under torture or ill-treatment should not be used in court. ${ }^{45}$ Nonetheless, as pointed out by the UN Special Rapporteur Philip Alston, not only were terrorist suspects held in Guantánamo subject to degrading and inhumane treatment, including torture, but also the information obtained through this method was used as evidence by the Military Commission Act. ${ }^{46}$

Furthermore, international human rights law imposes that people may be detained only in places officially recognised as a detention place, ${ }^{47}$ which renders secret detention places, such as 'black sites' used by the U.S. unlawful. In addition, even if the forced transfer of individuals is not prohibited under international law, customary international law imposes several limits to it, for instance, the prohibition to transfer persons when it would expose them to a real risk of being ill-treated or worse in the receiving state (obligation of nonrefoulement) ${ }^{48}$ For that reason, countries that cooperate with the US programme of extraordinary renditions and secret detention risk contravening their obligation of nonrefoulement. ${ }^{49}$

Enforced disappearances, i.e. a deprivation of liberty in which the individual's whereabouts is unknown and he or she is, put those individuals outside the protection of law, and, therefore, is absolutely prohibited, according to the UN Human Rights Committee. ${ }^{50}$ The Committee also states that the right to challenge the lawfulness of the detention is nonderogable ${ }^{51}$ and that even in times of armed conflict, the principles of necessity, proportionality, humanity and non-discrimination must be applied..$^{52}$

UNCAT (n 5) art 15; Saunders v United Kingdom App no 19187/91 (ECtHR, 17 December 1996) 68; Serves v France App no 20225/92 (ECtHR, 20 October 1997) 46; Inter-American Convention to Prevent and Punish Torture (entered into force 28 February 1987) OAS Treaty Series No 67 (1985) art 10; GK. $v$ Switzerland (2003) CAT/C/30/D/219/2002; UNGA (Human Rights Council), 'Report of the Special Rapporteur on Torture and Other Cruel, Inhuman or Degrading Treatment or Punishment' (10 April 2014) UN Doc A/HRC/25/60.

UNGA (Human Rights Council), 'Promotion and Protection of All Human Rights, Civil, Political, Economic, Social and Cultural Rights, Including the Right to Development. Addendum - Mission to the United States of America. Report of the Special Rapporteur on Extrajudicial, Summary or Arbitrary Executions' (27 May 2009) UN Doc A/HRC/11/2/Add.5 para 40. See also 'The Guantanamo Trials' (Human Rights Watch, 9 August 2018) <www.hrw.org/guantanamo-trials> accessed 15 May 2019. UNCHR (n 33) para 11.

UNHCR, 'The Principle of Non-Refoulement as a Norm of Customary International Law. Response to the Questions Posed to UNHCR by the Federal Constitutional Court of the Federal Republic of Germany in Cases 2 BvR 1938/93, 2 BvR 1953/93, 2 BvR 1954/93' (31 January 1994) para 6; Zaoui v Attorney General (No 2) (30 September 2004) 1 NZLR 690 34, 136; UNHCR, 'Advisory Opinion on the Extraterritorial Application of Non-Refoulement Obligations under the 1951 Convention relating to the Status of Refugees and its 1967 Protocol' (26 January 2007) <www.unhcr.org/4d9486929.pdf> accessed 15 May 2019; Matthew Pollard, 'Terrorism, Counterterrorism, and Human Rights' in Saul Takahashi (ed) Human Rights, Human Security and State Security: The Intersection (Vol 1)' ( ABC-CLIO LLC 2014) 108. Convention Relating to the Status of Refugees (adopted 28 July 1951, entered into force 22 April 1954) 189 UNTS 137 (Refugee Convention) art 33; UNCAT (n 5) art 3; El-Masri v Macedonia (n 10) 220; Alzery v Sweden (2006) UN Doc CCPR/C/88/D/1416/2005.

Communication No. 1327/2004, Grioua v Algeria, UN Doc CCPR/C/90/D/1327/2004 (2007), para 7.2. See also Declaration on the Protection of All Persons from Enforced Disappearance, UNGA Res 47/133 (18 December 1992) A/RES/47/133; Inter-American Convention on Forced Disappearance of Persons (adopted 6 June 1994, entered into force 28 March 1996) art 3; UNGA International Convention for the Protection of All Persons from Enforced Disappearance (adopted 20 December 2006, entered into force 23 December 2010) UN Doc A/RES/61/177.

Ibid. 
Moreover, the right to fair trial is also considered a non-derogable one.$^{53}$ In accordance with the principles of legality and the rule of law, '[d]eviating from fundamental principles of fair trial, including the presumption of innocence' is prohibited in all circumstances. ${ }^{54}$ Moreover, even if Article 4 of the International Covenant on Civil and Political Rights (ICCPR) permits derogation from some aspects of Article 14 (right to fair trial) in times of state of emergency, those derogations may never exceed what is 'strictly required by the exigencies of the actual situation' and must respect other non-derogable rights. ${ }^{55}$ Both international human rights law and international humanitarian law prescribe the obligation to respect this right. ${ }^{56}$ In fact, fair trial guarantees provided for by the international human rights law still apply during armed conflicts, subject to the very strict situations where derogation is allowed. ${ }^{57}$ Under international humanitarian law, depriving someone of this right even constitutes a war crime. ${ }^{58}$ Article 17 of the International Convention for the Suppression of the Financing of Terrorism, for instance, requires the fair treatment of any person detained, including respect for the rights and guarantees provided for by international human rights law. Article 21 of this Convention confirms that by stating that 'it shall [not] affect other rights, obligations and responsibilities of States and individuals under international law.'

UNCHR (n 51) para 7, 15; UNHCR, 'General Comment 32: Article 14 (Right to Equality Before Courts and Tribunals and to Fair Trial)' (2007) UN Doc CCPR/C/GC/32 para 6, 59; The Arab Charter of Human Rights expressly treats the right to fair trial under Article 16 of the Charter as non-derogable in times of emergency. See Arab Charter on Human Rights (n 43) art 4(2).

International Covenant on Civil and Political Rights 'General Comment 29' in 'Derogations during a State of Emergency' (2011) UN Doc CCPR/C/21/Rev.1/Add.11, para 11, art 24; ICCPR 'General Comment 32 , art 14' in 'Right to equality before courts and tribunals and to a fair trial (2007) UN Doc CCPR/C/GC/32, para 6 .

ibid.

Universal Declaration of Human Rights (adopted 10 December 1948 UNGA Res 217 A(III) [UDHR] art 10; Convention for the Protection of Human Rights and Fundamental Freedoms (European Convention on Human Rights, as amended) [ECHR] arts 5-7;African Charter on Human and Peoples' Rights [African Charter] (adopted 27 June 1981, entered into force 21 October 1986) (1982) 21 ILM 58, art 7; Organisation of American States [OAS], 'American Convention on Human Rights, "Pact of San Jose"' (22 November 1969)

$<$ https://www.oas.org/dil/access_to_information_American_Convention_on_Human_Rights.pdf $>$ accessed 15 May 2019, art 8; ICRC, 'Customary IHL: Rule 100, Free Trial Guarantees' $<$ https://ihldatabases.icrc.org/customary-ihl/eng/docs/v1_rul_rule100>accessed 16 May 2019; Common Article 3 of the Geneva Conventions; Geneva Convention Relative to the Treatment of Prisoners of War (Third Geneva Convention)(adopted 12 August 1949) 75 UNTS 135 art 84(2); Protocol Additional to the Geneva Conventions of 12 August 1949, and relating to the Protection of Victims of Non-International Armed Conflicts (Protocol II) (adopted 8 June 1977, entered into force 7 December 1978) 1125 UNTS 609, art 6(2); Protocol Additional to the Geneva Conventions of 12 August 1949, and relating to the Protection of Victims of International Armed Conflicts (Protocol I) (adopted 8 June 1977, entered into force 7 December 1978) 1125 UNTS 3, art 75(4).

ICRC, 'Customary IHL Database, Rule 100 on Fair Trial Guarantees' $<$ https://ihldatabases.icrc.org/customary-ihl/eng/docs/v1_rul_rule100> accessed 15 May 2019. See also, Louise Doswald-Beck and Sylvain Vité, 'International Humanitarian Law and Human Rights Law' (1993) International Review of the Cross <https://www.icrc.org/eng/resources/documents/article/other/57jmrt.htm> accessed 15 May 2019; Louise Doswald-Beck, 'Fair Trial, Right to International Protection', Max Planck Encyclopedia of Public International Law <https://opil.ouplaw.com/view/10.1093/law:epil/9780199231690/law9780199231690-e798> accessed 15 May 2009.

Additional protocol to the Geneva Conventions of 12 August 1949 and relating to the Protection of Victims of International Armed Conflicts (protocol I) (entered into force 7 December 1978) 1125 UN Treaty Series 3 , art 85 . 
It should be also noted that the use of military courts to try persons accused of terrorism offences is not prohibited by international law, but the use must comply with the obligation to guarantee the individual's right to be judged by an impartial and independent court, as well with all the other obligations enshrined in international human rights treaties and customary international law. ${ }^{59}$

Another point which is relevant to this discussion is the use of secret evidence by courts in national security-related cases. The UN Special Rapporteur Philip Alston pointed out the Military Commission Act enacted by US provided that the government can withhold from the defence the sources and methods by which evidences were acquired, and allows that detainees are convicted based on evidence that was never shown to them. ${ }^{60}$ However, the use of secret evidence constitutes a violation of the right to fair trial and the principle of equality of arms, since the persons accused have no access to the evidence against them, and, therefore, cannot properly defend themselves.

Finally, Article 6 of the ICCPR states that 'no one shall be arbitrarily deprived of his life.' It goes on to state that even in 'countries which have not abolished the death penalty, sentence of death may be imposed only for the most serious crimes in accordance with the law in force at the time of the commission of the crime' and that ' $[t]$ his penalty can only be carried out pursuant to a final judgment rendered by a competent court.' Thus, the use of death penalties to those suspects subject to the extraordinary rendition programme raises concerns,${ }^{61}$ mainly when considering that the imposition of death penalty follows a trial which most certainly did not comply with the international fair trial standards. Therefore, the imposition of such penalty under these conditions would be a violation to Article 6 of the ICCPR. ${ }^{62}$

In sum, extraordinary renditions involve the commission of numerous violations to international human rights law. As any violation to human rights, individuals are entitled to seek redress under national and/or international courts. ${ }^{63}$ What we will see, however, is that

trial'<https://www.un.org/counterterrorism/ctitf/en/right-fair-trial>accessed 16 May 2019; UN; Summary of the discussions held during the expert consultation on the administration of justice through military tribunals and the role of the integral judicial system in combating human rights violations, A/HRC/28/32 (2015). See note 63.

Philip Alston, Promotion and Protection of All Human Rights, Civil, Political, Economic, Social and Cultural Rights, Including the Right to Development - Report of the Special Rapporteur on extrajudicial, summary or arbitrary executions, Philip Alston-Addendum - Mission to the United States of America, A/HRC/11/2/Add.5 (2009), para 40. Although the Military Commission Act of 2006 was amended in order to ensure more fair trial guarantees to the prisoners, it is believed that the U.S. authorities still conceal the investigative methods in criminal cases, eroding the fair trial rights. See 'US: Secret Evidence Erodes Fair Trial Rights' (Human Rights Watch, January 2018) < https://www.hrw.org/news/2018/01/09/ussecret-evidence-erodes-fair-trial-rights>accessed 15 May 2019; Owen Bowcott, 'Secret evidence leads to downgrade of convictions over Stoke shooting' (Guardian, 22 May 2018).

Cassandra Stubbs, 'At Guantánamo, a Death Penalty Case Without a Death Penalty Lawyer'(ACLU 14 November 2017) <https://www.aclu.org/blog/national-security/detention/guantanamo-death-penaltycase-without-death-penalty-lawyer>accessed 15 May 2019; Alka Pradhan, 'Outside the United States, $\begin{array}{llllll}\text { Extraordinary } & \text { Rendition } & \text { Trial'(2011) } & 15 & \text { ASIL }\end{array}$ <https://www.asil.org/insights/volume/15/issue/29/outside-united-states-extraordinary-rendition-trial> accessed 12 May 2019.

International Commission of Jurists, 'Pakistan: end military trials of civilians': 'Such use of military courts to try civilians is inconsistent with international fair trial standards, and the imposition of the death penalty after such trials violates the right to life.' (2018) <https://www.icj.org/pakistan-end-military-trials-ofcivilians/> accessed 12 May 2019. 
the right to access to justice and all the rights derived from it, including the right to reparations, are also violated on the grounds of national security and secrecy.

\section{The Significance of State Secrets Privilege for Extraordinary Rendition}

What is going to be shown in this chapter is that not only states violate international human rights through the use of extraordinary renditions and secret detentions itself, but they also violate their international human rights obligations by failing to properly address these former violations. Such failure happens where the state-held evidences are not allowed to be revealed to the courts and victims on the ground that disclosure would risk national security. This ground is called 'state secrets privilege' and can be applied to criminal and civil lawsuits.

Many states developed such doctrine, which is a common law evidentiary privilege that enables governments to withhold secret information in legal proceedings. ${ }^{64}$ The claim of privilege may result in the rejection of a discovery request or even in the total dismissal of the case without appreciation by the court. ${ }^{65}$ It is often used as a way to shield the responsible authorities from being held accountable for their violations of human rights. This work intends to argue that the privilege may contravene the states' obligation to provide for effective investigation of all violations, prosecute the responsible persons and ensure they are punished according to the rule of law. The impact of the state secrets privilege on human rights can be seen in several legal cases of extraordinary rendition, as shown below.

\section{I Relevant Cases}

\section{III.I.I Nasr and Ghali v. Italy}

Also known as Abu Omar case, this case was judged on 23 February 2016 by the European Court of Human Rights. Nasr Osama Mustafa Hassan, or Abu Omar, an Egyptian refugee in Italy, was subject to the US extraordinary rendition programme in cooperation with the Italian Intelligence and Security Service (Servizio Informazioni e Sicurezza Militare). The applicant sustained that he had been stopped by the Italian authorities, put into a lorry, handed over to CIA authorities, transferred to a secret detention in Egypt, tortured and interrogated. Later, these facts were brought before the Tribunal of Milan, which convicted twenty-three American authorities, but was forced to dismiss the charges against five Italian agents because the state secrets privilege was invoked and confirmed by the Italian Prime Minister. ${ }^{6}$ Under the Italian law, when the state secrets privilege is invoked in a criminal case, and confirmed by the Prime Minister, the only authority vested with this prerogative power, the information cannot be used by the prosecutor or the judge in any way. ${ }^{67}$ The invocation of state secrets privilege for crucial evidence made it impossible for the court to convict the Italian authorities. ${ }^{68}$

Sudha Setty, 'Litigating Secrets. Comparative perspectives on the state secrets privilege' (2009) 75:1 Brooklyn Law Review 201<https://brooklynworks.brooklaw.edu/blr/vol75/iss1/4/>accessed 15 May 2019.

ibid.

Adler Monica Courtney et al, Milan Tribunal, Judgement of 4 November 2009 (application n 12428). Law 124 (on Intelligence System for the Security of the Republic) of 3 of August 2007 and Law 187 (New Provisions Governing State Secrets Privilege) of 13 August 2007.

Arianna Vedaschi, 'State Secret Privilege versus Human Rights. Lessons from the European Court of Human Rights Ruling on the Abu Omar Case' (2017) European Constitutional Law Review 166, 169. 
However, considering that the information at issue was already well known by the prosecutor and was already in public domain, the admission by the court of the secrecy argument is understood to have extended the privilege beyond the terms of the law. ${ }^{69}$ As a result, the application of state secrets privilege in this case is seen not as a mean to protect national security, but merely to shield public authorities from prosecution. ${ }^{70}$

The Italian Constitutional Court is the only institution with powers to perform judicial review on the legitimacy of the state secrets privilege, by analysing the classified documents. ${ }^{71}$ However, in this case, the court refrained from doing so by merely analysing the formal and procedural aspects governing the privilege. ${ }^{72}$ It did not even verify whether a link between the state secrets privilege and the reasons prescribed by law existed. ${ }^{73}$ The very law governing the secrecy says that it cannot be used for hiding acts against the constitutional order, which includes the fundamental human rights. ${ }^{74}$ By refusing to review the state secrets privilege, the Italian Constitutional Court left it entirely to the discretion of the Prime Minister, which presents a risk of arbitrary use of the privilege. ${ }^{75}$

When brought before the Strasbourg Court, it ruled that the cooperation of the Member States of the Council of Europe with the CIA's extraordinary renditions programme violated Article 3 (prohibition of torture and inhuman or degrading treatment), Article 5 (right to liberty and security), Article 8 (right to respect for private and family life) and Article 13 (right to an effective remedy) of the ECHR. The Court settled not only the ruling on extraordinary renditions, but also on the accountability of the Member States for failing to provide an effective remedy to victims of gross violations to human rights, even when the wrongful acts are carried out outside their territories. ${ }^{76}$ In this judgement, the Court stated that the claim of state secrets privilege is unlawful when in relation to evidence which is already in the public domain and when it is used as way to avoid the accountability of the responsible authorities. ${ }^{77}$ The Court also pronounced on the unlawfulness of the government's behaviour of not in fact implementing the punishments set by the domestic court to the foreign authorities subject to it. ${ }^{78}$

As such, the Court demonstrated that extraordinary rendition and enforced disappearances undermine the most basic human rights and the fundamental values of a democratic society. It reinforced that democratic states are bound to the rule of law, even when facing the horrible threat of terrorism. It also demonstrated that to protect these principles, it is of paramount importance to hold those who violate them accountable by granting an effective remedy to the victims, and thus, the use of state secrets privilege must remain an exception and be balanced with proper guarantees.

\section{III.I.II El-Masri}

Khalid El-Masri, a German citizen, alleged that during a trip to Macedonia, he was detained by Macedonian agents, kept in incommunicado detention in a hotel for several weeks for interrogation, blindfolded and handcuffed, handed over to the CIA agents, who beat him,

ibid 171.

ibid.

Law n 124//2007, art 40; 2011 Italian Criminal Procedure Code, art 202(8).

Vedaschi (n 69) 172-173.

Judgement n. 106 of 11 March 2009, Italian Constitutional Court, paras 8.1-8.4, 12.5.

Law n 124/2007, art 39(11).

Vedaschi, (n 69) 174.

ibid 167.

Nasr and Ghali v Italy, Jugement du 23 Février de 2016, ECHR, at 268-74.

ibid. 
removed his clothes, forced a suppository in his anus, covered his head with a bag, forcibly sedated him several times and transferred him to a black site in Afghanistan. In Afghanistan, he claims that he was again tortured and interrogated, and that he began a hunger strike to protest against his detention without charge. He says that his health deteriorated, but no medical care was given and after a while, he was allegedly force-fed through his nose. Five months from his first arrest, he claims that he was taken to Albania, his belongings were returned, and that he was instructed to walk down the way without turning back. He says that he met the Albanian authorities on the way, who asked for his passport and once they saw he had no visa, they returned him to Germany. No charges were ever filed against him.

El-Masri filed a civil claim in the U.S. District Court for the Eastern District of Virginia against the former Director of the CIA and the aviation companies that made his transport during the extraordinary rendition procedure. The case was dismissed on the ground of state secrets privilege ${ }^{79}$ after the U.S. government argued that the suit could not proceed without exposing confidential information related to national security and foreign affairs. ${ }^{80}$ The decision of the Court upheld the government argument by stating that the lawsuit could not proceed because the government would not be able to reply without revealing 'considerable detail about the CIA's highly classified overseas programs and operations' ${ }^{81}$ It also stated that 'while dismissal of the complaint deprives El-Masri of an American judicial forum for vindicating his claims, well established and controlling legal principles require that in the present circumstances, El- Masri's private interests must give way to the national interest in preserving state secrets. ${ }^{182}$

The case was finally brought before the European Court of Justice against Macedonia (the only country involved that was under the jurisdiction of the Court). The decision of the Court on this case was a landmark judgement on the cooperation of EU states with the programme of extraordinary rendition and enforced disappearances of the U.S. The Court stated that such cooperation violated the prohibition of torture and other cruel, inhumane and degrading treatment, as well as the prohibition on unlawful detention. ${ }^{83}$ The Court also ruled that there was a violation to the right to respect for one's privacy and family life, and to the right to an effective remedy. ${ }^{84}$

Moreover, in their concurring opinion, the Judges Tulkens, Spielmann, Sicilianos and Keller, stated that within the framework of the right to an effective remedy, the state violated the right to truth, which requires an effective investigation and plays an important role in 'strengthening confidence in public institutions and hence the rule of law'. ${ }^{85}$ Here the Court had no jurisdiction to rule upon the use of the state secrets privilege by the US, but it stated, nonetheless, that the privilege has 'often been invoked to obstruct the search for the truth'. ${ }^{86}$ It went on to declare that while there may be obstacles or difficulties which prevent progress in an investigation in a particular situation, an adequate response by the authorities in investigating allegations of serious human rights violations, as in the present case, may

El-Masri v Tenet, 437 F. Supp. 2d 530 (E.D. Va. 2005) 537.

Statement of Interest, Assertion of a Formal Claim of State Secrets Privilege by United States of America, El-Masri v Tenet, 437 F. Supp. 2d 530 (E.D. Va. 2005) 437.

El-Masri v. Tenet, 437 F. Supp. 2 d 530 (E.D. Va. 2006) 539.

ibid.

El Masri v Macedonia, (2012) (Judgement) 2067ECHR 211, 240.

ibid $248-60$.

El-Masri v Macedonia, Separate Opinion of Judges Tulkens, Spielmann, Sicilianos and Keller (2012) 2067

ECHR 1, 6.

El-Masri v Macedonia (2012) (Judgement) 2067 ECHR 191. 
generally be regarded as essential in maintaining public confidence in their adherence to the rule of law and in preventing any appearance of collusion in or tolerance of unlawful acts. For the same reasons, there must be a sufficient element of public scrutiny of the investigation or its results to secure accountability in practice as well as in theory ${ }^{87}$

The Court asserted that the inadequate investigation deprived the victim of being informed about the truth of the facts that victimised him and the role of those responsible for it. ${ }^{88}$ Therefore, the privilege violated the right of Mr. El-Masri to an effective remedy against the horrific violations that were committed against him, to the truth about what happened (a right that is owned by the victim, his relatives and encompasses the right to know of society in general), and it also hampered the state to comply with its obligation to carry out an effective investigation and to punish the ones responsible for these wrongful acts.

It should be noted that later it was officially acknowledged that El-Masri's extraordinary rendition was a case of mistaken identity, ${ }^{89}$ which reinforces the need for a court's scrutiny towards such measures.

\section{III.I.III Binyam Mohamed}

In 2002, Binyam Mohamed was allegedly detained in Pakistan while he tried to return to the United Kingdom, his place of legal residence. The Pakistani authorities supposedly handed him over to U.S. agents, who submitted him to interrogations without any access to a lawyer for four months. ${ }^{90}$ Subsequently, he claims that he was forced into a plane, blindfolded and taken to a black site in Morocco. ${ }^{91}$ There he alleges that he was detained, interrogated and tortured by Moroccan agents for a year and a half. According to him, his bones were routinely broken by them, he was beaten, cut with a scalpel all over his body, including his penis, and 'hot stinging liquid' was poured into his open wounds. ${ }^{92}$ In 2004, he is believed to have been taken by CIA agents and transferred to Afghanistan in a private aircraft. ${ }^{93}$ After months being interrogated and tortured there, he claims that he was taken to Guantánamo Bay. In the hands of American agents, he was tortured by inter alia being kept in constant darkness, barely fed and subjected to loud noises such as women and children screaming. At last, in 2005, he was charged with conspiracy by a U.S. military commission. He had supposedly confessed, but he says that he was forced to confess during torture. During his stay in Afghanistan, he was also questioned by British officials.

Later on, he tried to obtain with the British government proof that he has been tortured by U.S. officials to prove that his confession was obtained under torture. However, the British government refused to disclose the documents under the 'public interest immunity doctrine', the British equivalent to state secrets privilege. ${ }^{94}$

ibid 192.

ibid.

Glenn Kessler, 'Price to Admit German's Abduction Was an Error: On European Trip, Rice Faces Scrutiny on Prisoner Policy' (Washington Post, 7 December 2005) <http://www.washingtonpost.com/wpdyn/content/article/2005/12/06/AR2005120600083.html>accessed 30 June 2019; Dana Priest, 'Wrongful Imprisonment: Anatomy of a CIA Mistake' (Washington Post, 4 December 2005).

Jeffrey Davis, 'Uncloaking Secrecy: International Human Rights Law in Terrorism Cases' (2016) 38(1) Human Rights Quarterly 58.

Mohamed v Jeppesen Dataplan, Inc, 539 F. Supp. 2d 1128, 1130 (N.D. Cal. 2008)

Mohamed v Jeppesen Dataplan, Inc, 614 F.3d 1070, 1074 (9 $9^{\text {th }}$ Cir. 2010)

Davis, (n 90) 60.

ibid. 
He then brought the issue before the British courts. ${ }^{95}$ It was only when the case went to the High Court that the British government acknowledged they had documents that 'might be relevant in the context of proceedings before the Military Commissions. ${ }^{96}$ However, according to the government, disclosing those documents would cause 'significant damage to [the] national security of the United Kingdom' ${ }^{97}$ Under this new evidence, the High Court found that there was an 'arguable case', but it stayed its order to produce documents until the Foreign Secretary decided whether to invoke the public interest immunity. ${ }^{98}$

Later the Court made a redacted version of its decision to protect confidential information. ${ }^{99}$ However, the Foreign Secretary opposed to the release of the documents and the publication of the redacted paragraphs on the ground that US had threatened to reconsider its intelligence sharing cooperation with the United Kingdom if such documents were released. ${ }^{100}$ During the proceedings before the High Court, Mr Mohamed's habeas corpus petition was heard by the US Federal Judge Emmet Sullivan, who requested the US government to produce evidence to support the charges against him. At the end, the US government produced forty-two heavily redacted documents, ${ }^{101}$ which were considered by the British High Court as enough evidence to provide Mr Mohamed with an effective remedy before the British Court. ${ }^{102}$ However, the Court still needed to deal with the issue of the publication of the redacted decision. According to it, 'requirements of open justice, the rule of law and democratic accountability demonstrate the very considerable public interest in making the redacted paragraphs public, particularly given the constitutional importance of the prohibition against torture.' ${ }^{103}$ As such, the High Court dismissed the appeal of the Foreign Secretary, and held that the 'publication of the redacted paragraphs would not reveal information which would be of interest to a terrorist or criminal or provide any potential material of value to a terrorist or a criminal. ${ }^{104}$ This case shows that not only are counter-terrorism operations transnational, but that so are the efforts to keep information secret. ${ }^{105}$ However, the more transnational the efforts to fight terrorism, the more compelling it is to ensure that human rights are respected and that accountability for their violations is seriously taken.

The cases mentioned above illustrate the tension that exists between national security interests and international human rights law. The governments want to keep the clandestine aspects of their counter-terrorism operations secret, and most of the national courts recognise the right to keep this secrecy on national security grounds, making accountability for human rights violations very difficult. There is a huge risk - and indeed the cases mentioned herein demonstrate that the risk has been materialised - that governments make use of these secrecy

Mohamed, $R v$ Secretary of State for foreign \& Commonwealth Affairs (Rev 31-07-2009) [2008] EWHC 2048 (Admin) (21 August 2008) 2.

ibid 47.

ibid.

ibid $147,149$.

ibid 4.

Mohamed, $R v$ Secretary of State for foreign \& Commonwealth Affairs [2008] EWHC 2100 (Admin) (29 August 2008) 5,2 .

Mohamed, R v Secretary of State for foreign \& Commonwealth Affairs [2009] EWHC 152 (Admin) (04 February 2009) $5,7$.

Davis, (n 90) art 61-2.

Mohamed, $R$ v Secretary of State for foreign \& Commonwealth Affairs [2009] EWHC 152 (Admin) (04 February 2009), para 54.

Mohamed, $R v$ Secretary of State for foreign \& Commonwealth Affairs [2010] EWHC Civ 65 (Admin) (10 February 2010), para 52.

Davis, (n 90) art 63. 
doctrines to simply guarantee impunity to the human rights violations committed by their authorities.

\section{State Secrets Privilege and Human Rights}

As this work has shown in the previous chapters, the use of the state secrets privilege in cases concerning national security may serve as means to prevent public authorities from being held accountable for their violation to human rights. This shield itself is another violation to human rights, because states are not only bound to respect fundamental rights such as, inter alia, the right to life, the right not to be tortured or ill-treated, the right not to be arbitrarily detained, but also the right to be heard before a competent and impartial court, to receive a proper redress, to have those responsible for their injustices investigated and punished, to be ruled by a transparent government, to search the truth about the facts related to them and involving their government and to have a government that fights impunity in the name of democracy.

The right to fair trial, enshrined in Article 6 of the European Convention on Human Rights (ECHR), Article 14(1) of the ICCPR, Article 8 of the American Convention on Human Rights and, Article 7 of the African Charter on Human and Peoples' Rights, Article 13 of the Revised Arab Charter on Human Rights and Article 20 of the ASEAN Human Rights Declaration, is one of the fundamental guarantees of human rights and the rule of law. ${ }^{106}$ This right is essential for the enjoyment of the other fundamental rights. For this reason, it is paramount that every person has access to judicial protection, which is implemented by the access to court, to remedies and reparations.

In Myrna Mack Chang v. Guatemala, the Inter-American Court of Human Rights stated that allowing officials in the branch of the government under investigation to deny access to information on the grounds of secrecy constituted a violation to the right of judicial protection and to an investigation. ${ }^{107}$ For this Court, states are entitled to make some information secret, but this 'must be subject to control by other branches of State or by a body that ensures respect for the principle of the division of powers. ${ }^{108}$ It should be noted that while the US is not subject to the jurisdiction of this Court, the Inter-American Commission of Human Rights may decide on the lawfulness of its state secrets privilege jurisprudence. ${ }^{109}$

In El-Masri, the European Court of Human Rights stated that the right to an effective remedy 'requires independent and rigorous scrutiny of the claim that there exist substantial grounds for fearing a real risk of treatment contrary to Article 3 [prohibition of torture] ${ }^{110}$ and that ' $[\mathrm{t}]$ his scrutiny must be carried out without regard to any perceived threat to the national security of the expelling State. ${ }^{111}$ The Court also acknowledged that ' $[\mathrm{t}]$ he concept of 'State secrets' has often been invoked to obstruct the search for the truth.' ${ }^{112}$

The Inter-American Court of Human Rights recognised the right to truth, explaining that the right to an effective investigation and to truth derives from the obligation to protect

Basic Human Rights Reference Guide: Right to a Fair Trial and Due Process in the Context of Countering Terrorism, (October 2014) <https://www.ohchr.org/EN/newyork/Documents/FairTrial.pdf> accessed 12 May 2019. Myrna Mack Chang v. Guatemala, n. 101, Judgement of 25 November 2003, IACHR, 181.

ibid 180, 181.

Davis, (n 90) 71.

El Masri v Macedonia, (2012) (Judgement) 2067 ECHR, 257.

ibid.

ibid 191. 
people from violations to their rights and to grant them judicial protection. ${ }^{113}$ The state secrets doctrine prevents the victims, their relatives and the society from knowing the facts and wrongful acts committed by the governments in violation to fundamental human rights.

Moreover, the European Court of Human Rights also ruled that 'the confines of a democratic society governed by the rule of law cannot allow this system to operate in conditions of guaranteed impunity for the abuses committed by its agents.' ${ }^{114}$ Furthermore, the Court also stated that 'it should be possible to ensure accountability of the anti-terrorist and security services without compromising the legitimate need to combat terrorism and to maintain the necessary level of confidentiality. ${ }^{115}$

In addition, the Convention Against Torture and Other Cruel, Inhumane or Degrading Treatment or Punishment also imposes the obligation of the states to investigate and to punish allegations of torture. ${ }^{116}$

Even if the European Court of Human Rights' and the Inter-American Court of Human Rights' rulings are only binding to those countries that accepted their jurisdiction, because many of the rights and obligations stated by these courts are reflected in numerous sources of international law, these rights may be considered as reflecting customary international law, and therefore, binding on all the states of the planet. ${ }^{117}$ Those instruments of international human rights law and rulings demonstrate that the state secrets privilege cannot eliminate the right of the victims, their relatives or society to know the truth about these violations and that states cannot, on behalf of national security, breach their obligations under customary international law and human rights law toward the right to truth, to an effective investigation, to an effective remedy, and to judicial protection. Victims have the right to justice, and this means that their claims must be heard, that they have the right to know about the facts and people who victimised them, to see them punished, to receive proper redress, and those rights cannot be arbitrarily taken from them.

\section{IV.I National Security Versus Human Rights Dilemma}

In order to avoid the misuse of the state secrets privilege, the assessment of what must be kept secret or not must not be confined to the organ involved in the litigation at issue. Mainly when there is a claim of the existence of torture or ill-treatment or other gross violations to human rights, this claim deserves a close and independent scrutiny regardless of whether there is a matter of national security involved or not.

In this regard, Israeli practice should be noticed. In Public Committee Against Torture in Israel v. Israel, the committee challenged the use of preventive airstrikes by the Israeli forces against alleged terrorists. The executive branch of the government, however, claimed that the issue was not justiciable on the grounds of national security. ${ }^{118}$ Here the court established four criteria to assess if a case is justiciable before a court or not: (i) where there is human rights involved, the case is always justiciable; (ii) where the case involves mainly political or military policies and not a legal dispute, it is not justiciable; (iii) issues that have already been dealt with by international courts to which Israel is signatory, must be justiciable domestically as

Velásquez Rodrigues v. Honduras, N. 4, 29 July 1988, IACHR, 166; Blake v. Guatemala, Reparations, N. 48, 22 January 1999, IACHR, 63.

Aslakhanova v. Russia, (2012) (Judgement )2075 ECHR, 231.

ibid.

Convention against Torture and Other Cruel, Inhuman or Degrading Treatment or Punishment; Resolution 39/46, U.N. GAOR (1984), arts 12-14.

Davis, (n 90) 81. See also, (n 6), (n 49) and (n 60).

Public Committee Against Torture v. Israel, 2005 Isr HCJ 769/02. 
well; and (iv) a judicial review should be allowed when analysing the ex post objective application of a policy, rather than the policy itself. ${ }^{119}$ In this case, the court considered that the suit challenged not the policy on use of strikes in general, but their specific use against civilians, a subject which has already been considered by other international courts and that the analysis was over an ex post situation, despite of the classified military information involved. ${ }^{120}$ As such, the court ruled that the matter was justiciable, and the Israeli Supreme Court has consistently considered that matters related to national security are justiciable. ${ }^{121}$

In Adalah Legal Centre for Arab Minority Rights in Israel v. Minister of the Interior, considering the balancing test applied, the court explained that, even though the court is cautious when examining the security claims of the executive branch, it should examine the reasonableness of their claims and proportionality of the measure concerned when it involves a security policy in violation of human rights. ${ }^{122}$ Furthermore, in an attempt to preserve security, the Israeli courts often use in camera review without the presence of the parties or lawyers to assess the risk to national security. ${ }^{123}$

In Scotland, the courts have consistently struck a balance between national security interests and the interest in democratic accountability and individual rights. ${ }^{124}$ In Leven v. Young, the court held that the judiciary have the right to make an independent determination on the claim of the privilege over certain evidence. ${ }^{125}$ Nonetheless, the courts also stated that the party seeking the classified information should demonstrate a significant level of need for the disclosure to be granted. ${ }^{126}$

In Conway v. Rimmer, the court established the Scottish standard by saying that "[i]f, on balance, considering the likely importance of the document in the case before it, the court considers that it should probably be produced, it should generally examine the document before ordering the production". ${ }^{127}$ On the other hand, the court also established guidelines to define when greater deference should be given to the government in cases related to documents concerning national security, saying, however that in cases, such as litigations related to accidents involving state employees and on government premises, the crown privilege ought not to be invoked. ${ }^{128}$ The court further stated that "[i]mmunity from unauthorised disclosure and from accountability are two sides of the same coin". ${ }^{129}$ This balancing test set forth in Conway is still applied today in cases concerning state secret privilege in Scotland.

These approaches demonstrate the importance of striking a fair balance between human rights and the interests of national security. An independent and impartial organ must be always responsible for scrutinising the implications of the executive branch's measures on the human rights of the affected persons. Cases involving grave violations to human rights

ibid 50-54.

ibid 8, 51, 19-46, 56, 54.

See for instance, Schnitzer v Chief Military Censor, 1989 Isr. HCJ 680/88.

Adalah Legal Centre for Arab Minority Rights in Israel v. Minister of the Interior, 2006 Isr. HCJ 7052/03 443, 692693.

See for instance, Vanunu v. Head of the Home Front Command, 2004 Isr. HCJ 5211/04.

ibid.

Leven v. Young (1818) 1 Murray (Scot. $1^{\text {st }}$ Div) 350, 370.

William Weaver and Danielle Escontrias, 'Origins of the State Secrets Privilege'(2010) Social Science Research Network, SSRN 37.

Conway v. Rimmer, A.C. (1968), 911.

ibid 923.

ibid 924 . 
should be always justiciable, and courts should implement measures, such as in camera reviews if necessary, to guarantee that human rights will always be protected, even when the need to preserve national security demands secrecy. In addition, having the victims prove the violations of their rights in cases in which all the evidence is in the custody of the state is unfair and inhuman. ${ }^{130}$ In such cases, the burden of proof must be shifted to the state responsible for the alleged violations.

Democracy requires that impunity within the state institutions be fought and this can only be achieved through the mechanism of checks and balances - in this case, through the scrutiny of the judiciary over the executive branch.

\section{Final Conclusion}

Whereas it is of paramount importance that governments fight terrorism, a phenomenon that threatens our society as it is and the very essence of fundamental human rights, it is also critical that they do not relinquish human rights while doing so. Unfortunately, what we have seen during the past years is an increasing abuse by states of their prerogatives on behalf of combating the impunity of terrorism. Individuals are detained, kidnapped, tortured and even killed in a manner which completely falls short of complying with human rights obligations, both at national and international levels.

Any democratic state based on the rule of law is bound to have judicial mechanisms to ensure that human rights are protected against the possible arbitrariness of government agents in any circumstance. The only way to guarantee that the executive branch of the government does not abuse its prerogatives and becomes arbitrary is through a system of checks and balances, inherent to the principle of separation of powers. Where the courts cannot exercise their prerogatives to scrutinise the activities of the government in order to guarantee compliance with the rule of law and human rights, democracy is no longer existent. It is part of the functions of the judiciary branch of the government to scrutinise the measures taken by the executive branch that may contravene the law, mainly when the law is that of human rights. Courts must make sure that governmental activities fall within the framework of legality, and to do so it is essential that impunity does not take place.

In many instances, however, the state secrets privilege has been used as a way to shield state officials from prosecution and punishment. While this work acknowledges the need of secrecy to protect the interests of national security, it considers that the information about the responsibility of those involved in gross violations against human rights, such as torture, enforced disappearance and murder should not be kept a secret.

Furthermore, the use of state secrets privilege over information that is already known by the plaintiff or that is already in public domain cannot be regarded as anything but an attempt by the government to shield its wrongful acts from public or judicial scrutiny, and, therefore, courts should not accept this claim. A distinction must be made between legitimate secrets and those which do not deserve protection.

Allowing the executive to decide upon their own mistakes and to make them secret would deprive not only the courts of their role, but also the plaintiffs of their right to a fair trial, to the truth and to an effective remedy and reparations. Moreover, it is clear from all the information that came to public knowledge that the use of the secrecy privilege cannot be simply left to the assumption of good faith of the executive. 
For this reason, it is fundamental that the judiciary exercises its prerogatives to at least check if the claim of secrecy has a legitimate ground, and, even in cases where it does, to develop a way to ensure as much as possible that the victims are protected by the courts and the perpetrators are punished. As such, procedural safeguards must be put in place to guarantee that a fair balance is struck between the interests of national security and the interests of preserving transparency and protecting human rights. For instance, in cases involving torture, forced disappearances or other gross violations of human rights, the burden of proof should be shifted to the government instead of having the victims or their relatives to prove what happened to them. Without judicial oversight, the prohibitions to torture, to arbitrary detention and killings are meaningless. Finally, it is only by embracing human rights that society and its values can be preserved. 